\title{
Custos invisíveis - conflitos de interesses e o não registro de juros, multas e atualizações monetárias: o caso da Universidade de Brasília
}

\author{
Andrea Felippe Cabello \\ Universidade de Brasília (UnB) \\ Joelder Alves da Silva \\ Universidade de Brasília (UnB)
}

O estudo analisa a não contabilização de juros, multas e atualizações monetárias advindos do atraso nos pagamentos das faturas de energia elétrica e telefonia fixa nas despesas orçamentárias da Universidade de Brasília (UnB), como possíveis custos invisíveis. Apresenta-se uma análise sobre a representatividade financeira desses custos perante os recursos destinados para custeio das atividades institucionais. Relaciona-se essa situação com a ineficiência de processos na organização e com a falta de incentivos de agentes para reportar problemas, utilizando-se a teoria da agência para justificar conclusões. Também por meio dessa teoria se apresentam as políticas de incentivo e controle, que não devem ser descartadas dentro de um processo resolutivo.

Palavras-chave: despesa pública, gestão orçamentária, estudo de caso

Costes invisibles - conflictos de intereses y el no registro de intereses, multas y actualizaciones monetarias: el caso de la Universidade de Brasília

Resumen: El estudio analiza la non contabilización del interés y sanciones de los atrasos en los pagos de las facturas de energía y telefonia en el gasto presupuesto de la Universidad de Brasília (UnB), los costos invisibles. Se Presenta un análisis de la representatividad financiera de los gastos frente los ingresos para lo financiamiento de las actividades institucionales. Se Relaciona esta situación com la ineficiência de procesos en la organización y con la falta de incentivos de agentes para reportar cuestións, utilizandose la teoria de la agência para justificar nuestras conclusiones. También com esta teoria, se presentan políticas de incentivo y controle, que no pueden ser descartadas en un proceso resolutivo.

Palabra Clave: gasto público, gestión presupuestaria, estudio de caso

[Artigo recebido em 2 de outubro de 2015. Aprovado em 5 de maio de 2016.] 
Invisible costs - conflict of interests and the absence of register of interests, fines and monetary restatements: the case of the University of Brasília

Abstract: This study analyzes the lack of accounting of interests and penalties due from the delay of payments of electric and telephonic bills in budget expenses of the University of Brasilia, as possible invisible costs. We present an analysis regarding how financially important are these costs considering other resources used for institutional activities. We relate this situation with process inefficiency in the organization and with the lack of incentives to report problems, using agency theory to justify our conclusions. Through this theory, we also present policies of incentive and control which cannot be ignore in a resolutive environment.

Keywords: public expenditure, budgetary management, case study 


\section{Introdução}

Subestimar custos ocasionados pelo excesso de ineficiência nos procedimentos administrativos internos e por desperdícios de recursos advindos, por exemplo, das tarefas para organizar as transações dentro da firma pode ter um papel insignificante em algumas estruturas organizacionais. Porém, o seu engajamento traz o principal motivo que diferencia a eficiência entre duas empresas do mesmo ramo no mercado competitivo.

Gerir estrategicamente os custos tem uma aplicabilidade muito importante como instrumento gerencial na condução dos negócios. A preocupação econômica está centrada principalmente no processo de tomada de decisão, no sentido de se saber o quanto, quando e onde deverão ser investidos e/ou reduzidos os gastos.

Portanto, para que essa alocação de recursos seja eficiente e conduza ao processo de melhoria de resultados, é necessária, antes, uma análise mais profunda e adequada dos custos que envolvem determinada atividade. É necessário, ainda, dispensar, por exemplo, uma maior atenção aos custos que são de difícil percepção e mensuração, pois podem ser representativos. Nesse sentido, a correta determinação dos preços dos bens e serviços é imprescindível, de forma a garantir o equilíbrio de mercado, uma vez que não precificados adequadamente podem conduzir a uma alocação ineficiente.

Nessa perspectiva, a teoria econômica vem tratando de diversos tipos de custos que são de difícil mensuração, mas que nem por isso devem ser negligenciados na análise. Segundo Ferreira (2014), a questão dos custos invisíveis muitas vezes relaciona-se com a dificuldade de se mensurar aquilo que é incerto ou muito distante da realidade dos tomadores de decisão. Entretanto, em diversas áreas, a teoria econômica avança buscando resolver a questão. Por exemplo, a abordagem dos custos de transação tornou-se base para o entendimento e análise de diversas questões sobre estudos organizacionais. Sua definição está ligada aos custos decorrentes da negociação de contratos entre agentes econômicos e pode assumir um importante papel no processo de distribuição e gestão dos recursos quando não subestimados.

As primeiras ideias dessa base teórica foram lançadas por Coase (1937), ao assumir que as firmas podem organizar-se na busca de redução de custos de informação, negociação e contratos, quando para a obtenção de produtos e serviços no mercado. No entanto, tal análise, importante para as decisões entre internalizar determinada produção ou contratar de outra empresa, fica comprometida justamente pela 
dificuldade de mensuração dos custos econômicos dessas transações, sendo essa uma das principais críticas a essa literatura.

Outro tipo de custo de mensuração difícil são os custos de oportunidade, definidos como aqueles custos associados às oportunidades que serão deixadas de lado, caso a empresa não empregue os recursos da melhor maneira possível.

Considerando que a mensuração dos custos de transação e de oportunidade é algo tecnicamente difícil, além de demandar significativos investimentos, tanto de recursos financeiros quanto de tempo de pesquisa, a atenção desvia-se para os casos dos custos que não são, a priori, perceptíveis e passíveis de quantificação no momento em que ocorrem: os chamados custos invisíveis (ALEXANDRE, 2002). A gestão dos custos invisíveis sustenta-se na possibilidade de se gerir custos controláveis e não mensurados, seja pelo aspecto contábil ou por seus tradicionais sistemas de acumulação de custos, mas que, no entanto, devem ser identificados e mapeados para que os gestores tomem conhecimento de sua existência de maneira a lhes permitir uma atuação incisiva sobre eles.

Identificar um custo, decorrente de uma transação entre agentes econômicos, que, por vezes, não é visualizado ou passa despercebido, por mínimo que seja ele, pode representar uma despesa considerável, quando contabilizados numa projeção mais longa, contribuindo significativamente para as decisões alocativas. Portanto, apesar de serem invisíveis ou ocultos, trata-se de custos perfeitamente gerenciáveis e que podem ensejar a sua adequada avaliação na abordagem econômica de custos de transação, de oportunidade, entre outros, complementando assim uma lacuna teórica existente e questionando o motivo dessa não contabilização.

Dessa forma, busca-se aqui realizar tal análise, por meio de um levantamento mais criterioso de algumas situações em que o custo invisível pode estar presente, observando as relações transacionais entre a Universidade de Brasília (UnB) e empresas externas prestadoras de produtos e serviços. Especificamente, são analisados os valores referentes a multas e juros contratuais advindos do atraso nos pagamentos e que não são registrados como tais no momento do pagamento das contas, impedindo o agente de tomar decisões eficientes de forma a reduzir tais encargos. Normalmente, esses não são previstos contabilmente, uma vez que se trata de algo indesejável e que não pode existir por ser proveniente de falhas na gestão. Porém, apesar de não estarem evidenciados nos sistemas de controle da universidade, esses gastos são contabilizados financeiramente, uma vez que foram executados. Assim, a sua invisibilidade se torna ainda mais forte quando tais valores deixam de ser registrados nas contas contábeis específicas e acabam sendo pagos como normais. Isso impossibilita uma distinção econômica entre o que é serviço e o que é encargo por atraso. 
Diante dessa perspectiva, nosso objetivo geral é o de verificar o impacto de custos invisíveis nas despesas orçamentárias de custeio da UnB e trazer uma análise sobre a representatividade financeira desses custos e os aspectos de gestão que contornam o seu surgimento.

Nesse último ponto, a teoria da agência trouxe o entendimento de que as incidências dos custos invisíveis também estão ligadas à atuação dos envolvidos quando da execução das suas atividades. Assim, o seu comportamento pode, por vezes, não estar em sintonia com os interesses da organização, o que gera um conflito entre o agente e o principal.

Laffont e Martimort (2009) observam que o problema da relação agente-principal surge quando os agentes perseguem seus próprios objetivos, e não os da instituição. E os resultados desse estudo comprovam que algumas ações vão ao encontro disso e que políticas de incentivos e controle podem ajudar a resolver o problema.

O artigo se divide em oito seções, além desta introdução. A segunda seção discute os aspectos contábeis da noção de custos, enfocando nos custos invisíveis, enquanto a terceira seção trata da visão econômica sobre esses. A seção quatro discute a teoria da agência e o modelo principal-agente. A seção quinta descreve nossa metodologia, enquanto a sexta traz os resultados. Já a sétima discute problemas de gestão à luz do problema principal agente, enquanto a oitava traz os comentários finais.

\section{Aspecto contábil da noção de custos}

No âmbito da contabilidade empresarial, buscando uma distinção entre custo e despesa de forma mais criteriosa, tem-se que a despesa é um gasto ocorrido em um determinado período e lançado contabilmente nesse mesmo período, para fins de apuração do resultado periódico da empresa. Portanto, a despesa é lançada diretamente na demonstração de resultados, significando, no momento de sua ocorrência, uma redução de riqueza da empresa (PADOVEZE, 2006). Já o custo, para fins contábeis, está ligado à aquisição de mercadorias para estoque (no caso de empresas comerciais) ou insumos para fabricação de produtos (industriais). Enquanto estiverem em estoque, o valor pago ou incorrido para a obtenção da mercadoria ou insumo não seria uma despesa e sim um custo, pois não reduz a riqueza efetiva dos sócios. Dessa forma, todos os gastos ocorridos no produto, até que esse fique pronto para a venda, são tidos como custos de produção. O custo, por fim, se transforma em despesa quando o bem ou o serviço que estava estocado for consumido ou vendido. Portanto, a sua saída é uma "perda" para a empresa, uma despesa, e afeta a riqueza, positivamente ou negativamente, dependendo do resultado. 
Quando se analisa a diferença conceitual entre despesa e custo no âmbito do setor público, contexto do presente estudo, verifica-se que a despesa é a denominação que se aplica à utilização de recursos do Estado no custeio das atividades, seja na manutenção, prestação de serviços ou na realização de investimentos e outros gastos voltados para o desenvolvimento da economia (Albuquerque; Medeiros; Feijó, 2008). Já o custo mede o consumo de recursos pelas atividades das organizações governamentais (custo da atividade ou de processo). Alonso (1999) exemplifica ao afirmar que, quando a administração pública compra material de consumo, são feitos dois lançamentos contábeis de mesmo valor nas contas: o primeiro, despesa com material de consumo (despesa); e o segundo, estoque de material de consumo (ativo). A despesa só é contabilizada como custo no momento em que alguma unidade ou setor faz a requisição do material de consumo junto ao almoxarifado. $A$ contabilização da despesa como custo requer a apropriação dessa a algum produto (no custeio tradicional), ou a alguma atividade (no custeio baseado em atividade).

Nesse sentido, segundo Alonso (1999), basta lembrar que as despesas nos mostram como o governo financia os recursos que usa ou potencialmente poderá utilizar, como: a despesa com pessoal, material de consumo, equipamentos ou material permanente, serviços de terceiros, despesas financeiras etc. Enquanto isso, os custos nos mostram como o governo financia seus resultados: custo de uma aula, de uma consulta médica, de um serviço administrativo, custo de uma operação de fiscalização etc. Portanto, diferentemente do setor privado, suas preocupações com a gestão de custos não estão relacionadas com a avaliação de estoques ou com a apuração de lucros, mas sim com a melhoria da qualidade dos serviços públicos prestados.

\section{Custos invisíveis}

Do ponto de vista contábil, custos invisíveis ou custos ocultos (LIMA, 1991) são aqueles gastos que normalmente não são contabilizados nas despesas mensais e para os quais não há programação ou gerenciamento, por vezes, apesar de se saber que existem. $O$ que caracteriza os custos invisíveis é que aparentemente não se desembolsa nada no momento em que ocorrem seus eventos geradores e por isso pouca importância é dada aos mesmos, esquecendo-se de que, futuramente a cobrança, inesperada ou não, acontecerá e acarretará um prejuízo que poderia ser evitado ou ainda uma oportunidade de negócios perdida.

Femenick (2005) distingue entre estes dois tipos de custos: para esse autor, custos invisíveis relacionam-se com problemas estruturais internos ou externos à empresa e aparecem em comparação com a concorrência, enquanto os custos ocultos surgem por ineficiência de gestão resultando na queda do faturamento. 
De forma a tornar mais claro como esses gastos ou custos podem aparecer dentro da organização, Zaffani (2006) apresenta uma proposta distribuída em seis áreas do campo da gestão, a saber, relações humanas (relacionado ao clima organizacional), controles (relacionados a controles internos em excesso que não agregam valor), pessoal (problemas de motivação e interesse), recursos materiais (gerados pela ociosidade de ativos e problemas de manutenção), gestão (relacionados com o uso de sistemas e processos inadequados) e treinamento/qualidade (ligados à falta de eficiência e ineficácia).

Lima (1991) ainda afirma que a razão pela qual as empresas raramente medem e verificam os custos ocultos é que esses se encontram esfacelados e disseminados por toda a organização, além de não fazerem parte dos procedimentos de engajamento financeiro. Tais custos podem até parecer insignificantes, se tomados, por base comparativa, os gastos totais contabilizados. Porém, eles são habituais e podem resultar em uma despesa muito grande se forem contabilizados mensalmente, sendo que poderiam ser cortados ou, pelo menos, reduzidos caso haja uma maior atenção por parte dos gestores. Para Lima (1991), é o recolhimento desses microcustos que resulta em montantes exorbitantes e não uma localização precisa nesta ou naquela parte da empresa. Há estimativas que colocam tais custos entre $20 \%$ e $30 \%$ dos dispêndios totais das companhias ${ }^{1}$.

Consideramos que o problema da Universidade de Brasília se encaixa nessa situação, pois, conforme argumentaremos, trata-se de um problema de gestão. Essa falha de gestão, que se relaciona com os pontos levantados por Zaffani (2006), leva à não contabilização dos custos de multas e juros, ou seja, por uma falta de controle e planejamento, podem-se pagar contas em atraso, sem muitas vezes perceber o prejuízo que o problema de gestão está causando.

\section{Abordagem econômica sobre custos}

Até aqui, foi dada uma ênfase contábil e orçamentária para o tratamento de custos. Entretanto, a teoria econômica alega que, para uma eficiente alocação de recursos, é necessário que os bens (mesmo aqueles providos pelo Estado) estejam adequadamente precificados. Problemas com precificação surgem quando há externalidades presentes ou quando algum custo econômico não é considerado na questão, como, por exemplo, custos de oportunidade não monetários, custos de transação e custos de agência. O problema surge aqui muitas vezes pela dificuldade de mensuração desses custos, já que custos econômicos diferem de custos

\footnotetext{
${ }^{1}<$ http://www.amcham.com.br/business-in-growth/noticias/custos-invisiveis-das-companhias-representam-de-20-a-30-do-total>
} 
contábeis. A existência de custos invisíveis, nesse caso, levaria a uma precificação inadequada, prejudicando o equilíbrio alocativo da economia.

Uma das principais contribuições para a discussão de custos é a de Alchian (1977), que discute a natureza econômica do custo. O custo de oportunidade é representado pelo valor das oportunidades sacrificadas, ou seja, não escolhidas. Diferente dos custos contábeis que são escriturados na contabilidade de uma empresa, o custo de oportunidade é um custo implícito, que não aparece nos demonstrativos, porém é bastante utilizado no campo da economia quando do processo decisório. Raramente os custos de oportunidade são incorporados aos relatórios financeiros formais, por não implicarem, segundo Horngren, Foster e Datar (2000), recebimentos ou desembolsos de caixa. O registro contábil está limitado às alternativas selecionadas, em vez das alternativas rejeitadas, porque, uma vez que a alternativa é rejeitada ou deixada de lado, não haverá transações para registrar.

Segundo Nascimento e Souza (2003), para fins decisórios, os economistas entendem que a aplicação do conceito de custos de oportunidade na mensuração dos custos de um bem é o método que mais reflete a eficácia do gestor no gerenciamento dos recursos utilizados. Isso se dá justamente por ser uma decisão que envolve a escolha do melhor benefício ou retorno que cada alternativa de decisão poderia proporcionar em face do respectivo recurso.

No entanto, esse custo só aparece claramente após as alternativas terem sido elencadas e mensuradas. Dependendo da situação a ser analisada, uma coerente comparação entre as alternativas pode ser prejudicada, segundo Corrêa e Lopes (2009), devido à dificuldade de mensuração de alguns fatores subjetivos, como: riscos, incertezas, aspectos humanos e intangíveis. Ele ainda observa que, apesar da quantificação ser difícil, sua importância não perde valor, e os efeitos dos fatores subjetivos podem ser ainda mais impactantes do que os fatores objetivos mais explícitos (receitas e custos previstos).

\section{Economia dos custos de transação (ECT)}

Inicialmente a ideia da teoria econômica dos custos de transação surgiu com o estudo de Coase (1937) sobre a natureza das firmas. Ele ressalta o motivo da existência das firmas ou o porquê de se organizar uma firma, tendo o mercado como uma economia especializada em troca. Uma razão apontada é que a firma emerge porque os custos dos mecanismos de preço ou de se operar no mercado 
são maiores do que se realizados na firma. Seu estudo procura compreender porque as firmas são responsáveis pela própria produção ou optam por sua terceirização.

O ponto de partida da teoria do custo de transação é a consideração de que a empresa não possui apenas os custos de produção, mas também os custos das relações entre agentes econômicos para obtenção de produtos, insumos e serviços no mercado. Tais custos envolvem os custos de informação, negociação e celebração de um contrato (negociar, redigir e garantir o cumprimento do contrato).

Kupfer e Hasenclever (2013) definem custos de transação como aqueles que os gestores enfrentam toda vez que recorrem ao mercado para obter produtos ou serviços. De maneira mais clara, seriam os custos de negociar, redigir e garantir o cumprimento do contrato, como citado anteriormente. Tem-se, dessa forma, o contrato como a unidade básica de análise.

Para Coase (1937), uma empresa poderia, por meio de duas maneiras, realizar a função de reduzir os custos de transação: por meio dos mecanismos de preços, o que possibilitaria à empresa escolher os mais adequados para suas transações no mercado; e por meio da substituição de um contrato incompleto por vários completos. Porém, o autor ainda observa que é preciso ter atenção, pois os custos de se descobrir quais são os preços mais adequados e os de negociação de contratos podem ser relevantes e esvaziar o objetivo da redução.

Nessa perspectiva, Coase (1960) cita que as empresas, ao realizar transações, necessitam descobrir quem é a outra parte com a qual se deseja negociar e em que termos se conduzirá essa negociação.

"[...] formular o contrato, empreender meios de inspeção para se assegurar que os termos do contrato estão sendo cumpridos, e assim por diante. Tais operações são, geralmente, extremamente custosas, suficientemente custosas para evitar a ocorrência de transações que seriam levadas a cabo em um mundo em que o sistema de preços funcionasse sem custos" (COASE, 1960, p.13).

Dessa forma, segundo Kupfer e Hasenclever (2013), os custos de transação deixam de ser desprezíveis e passam a ser um elemento importante nas decisões dos agentes econômicos, pois contribuem para determinar a forma pela qual serão alocados os recursos.

Williamson (1985) cita que é importante compreender as origens e funções das diversas estruturas da empresa e do mercado. A questão que ele se propôs estudar é como essas instituições (mercados, firmas e contratos) lidam com os problemas vinculados à transação, uma vez que a utilização do mecanismo de mercado implica 
custos. Entre os problemas, ele considerou que os agentes econômicos possuem racionalidade limitada e são oportunistas. Isso aumenta os custos de transação, já que os agentes envolvidos precisam se proteger dos riscos associados às relações transacionais.

A racionalidade limitada, complexidade e incertezas criam as condições adequadas para que haja iniciativas oportunistas, bem como a geração de assimetrias de informação que podem afetar o resultado final da transação diante das diferenças de informação.

Para Williamson (1985), ao realizarem as trocas, os agentes participam de transações, as quais se distinguem por três características básicas: frequência, incerteza e especificidade dos ativos. O primeiro atributo, frequência, está associado ao número de vezes que os dois agentes realizam determinadas transações; o segundo relaciona-se aos efeitos não previsíveis a que as transações estão sujeitas; ea especificidades dos ativos relaciona-se com os custos advindos da não possibilidade de alocação alternativa daquele ativo em outra transação qualquer. Zylbersztajn e Neves (2000) reconhecem que, dessas três características, a especificidade dos ativos é aquela mais destacada pela teoria e de melhor visualização em torno do problema do desenho contratual e permite uma caracterização precisa e mensurável das relações.

Williamson (1996) observa que, na análise da ECT, os custos ex-ante e ex-post das transações devem ser considerados. Os custos ex-ante são aqueles relacionados com o desenho do contrato, a negociação e a criação de garantias ao acordo estabelecido. Os custos ex-post resultam das necessidades de ajustes e adaptações quando ocorrem falhas, erros e omissões na execução dos contratos, que possam gerar disputas entres as partes.

Nesse sentido, Zylbersztajn (2003) reitera que algumas metodologias para mensuração de custos de transação focam somente as transações ex-ante, ignorando aspectos ex-post das transações, o que gera limitações. O modelo desenvolvido por Williamson (1996) para o estudo dos mecanismos de governança tem um caráter comparativo e também observa a questão da dificuldade efetiva da mensuração dos custos de transação.

Portanto, a mensuração de custos de transações não é uma tarefa trivial. Essa é uma das críticas apresentadas à ECT, conforme observa Ferreira et al. (2005). Destaca-se que o valor absoluto da transação não interessa e sim os custos relativos associados às diferentes escolhas organizacionais ou contratuais (WANG, 2003). 
Percebe-se que, para alcançar a eficiência no uso dos recursos, tanto na esfera pública quanto privada, deve-se levar em conta a existência de situações que não são perceptíveis, num primeiro momento, pela área contábil. Portanto, se a gestão tiver um foco apenas nos demonstrativos contábeis, custos importantes e de grande representatividade, como os de oportunidade e de transação, serão deixados de lado durante o processo decisório alocativo.

\section{A teoria da agência e o problema principal-agente}

Além dos aspectos abordados relativos à eficiência na alocação dos recursos, que envolve a análise adequada dos custos econômicos e precificação dos bens e serviços, a incidência dos custos invisíveis também pode estar ligada aos reflexos da atuação dos envolvidos perante a execução das suas atribuições. Há situações em que os administradores e funcionários de determinada organização podem agir conforme suas preferências e interesses, perseguindo suas próprias metas e objetivos em vez do estabelecido pelos donos da empresa, ou, ainda, por haver um baixo incentivo ou estímulo, podem apresentar um desempenho aquém de suas potencialidades.

Nesse sentido, observa-se a ideia de que os agentes são, em sua maioria, dotados de racionalidade limitada e propensão ao oportunismo, de maneira que o seu comportamento pode, por vezes, não estar em sintonia com os interesses da organização. Haverá, desse modo, um conflito capaz de gerar perdas e gastos para a organização, como, por exemplo, os custos invisíveis analisados sob a perspectiva deste estudo.

Nesse contexto, a teoria da agência visa analisar os conflitos e os custos resultantes da separação entre o principal, aquele que delega tarefas ou o seu poder de autoridade, e o agente, que passaria a ser o responsável pela execução. Segundo Laffont e Martimort (2009), a relação de agência existe sempre quando há uma interação entre pessoas, em que o bem-estar de uma pessoa depende daquilo que é feito por outra. $\mathrm{O}$ agente corresponde à pessoa atuante, executora, e o principal será a parte afetada pela ação desse agente (acionista ou proprietário). Trata-se de uma situação que envolve a delegação de alguma autoridade para a tomada de decisão do agente.

Um exemplo comum na literatura referente ao problema principal-agente está na possibilidade da não participação do acionista no gerenciamento da empresa, em que a responsabilidade do acionista para com a organização é limitada à parcela de capital que ele investiu. Desvincula-se, portanto, o investidor da administração da empresa, o que conduz a um importante problema de agência, pois o processo de decisão vai 
para as mãos de administradores profissionais cujos interesses não são idênticos àqueles dos investidores, além de que os meios de que dispõem os acionistas para controlar o comportamento dos administradores são limitados e imperfeitos.

Apesar da maioria das referências abordarem o agente e o principal como sendo, respectivamente, administrador e proprietário, essa noção de relação se apresenta também de diferentes formas, com diferentes atores e em diferentes ambientes, conforme o Quadro 1.

\section{Quadro 1 - Relações entre principal e agente}

\begin{tabular}{|c|c|}
\hline Principal - Agente & O que o principal espera do agente? \\
\hline Acionistas - Gerentes & $\begin{array}{l}\text { Gerentes maximizem a riqueza do acionista (ou o } \\
\text { valor das ações) }\end{array}$ \\
\hline Debenturistas - Gerentes & Gerentes maximizem o retorno do debenturista \\
\hline Credores - Gerentes & $\begin{array}{l}\text { Gerentes assegurem o cumprimento dos contra- } \\
\text { tos de financiamento }\end{array}$ \\
\hline Clientes - Gerentes & $\begin{array}{l}\text { Gerentes assegurem a entrega de produtos de } \\
\text { valor para o cliente - qualidade (maior), tempo } \\
\text { (menor), serviço (maior) e custo (menor) }\end{array}$ \\
\hline Governo-Gerentes & $\begin{array}{l}\text { Gerentes assegurem o cumprimento das obri- } \\
\text { gações fiscais, trabalhistas e previdenciárias da } \\
\text { empresa. }\end{array}$ \\
\hline Comunidade - Gerentes & $\begin{array}{l}\text { Gerentes assegurem a preservação dos interesses } \\
\text { comunitários, cultura, valores, meio ambiente etc. }\end{array}$ \\
\hline Acionistas - Auditores externos & $\begin{array}{l}\text { Auditores externos atestem a validade das de- } \\
\text { monstrações contábeis (foco na rentabilidade e na } \\
\text { eficiência) }\end{array}$ \\
\hline Credores - Auditores externos & $\begin{array}{l}\text { Auditores externos atestem a validade das } \\
\text { demonstrações contábeis (foco na liquidez e no } \\
\text { endividamento) }\end{array}$ \\
\hline Gerentes - Auditores internos & $\begin{array}{l}\text { Auditores internos avaliem as operações na ótica } \\
\text { de sua eficiência e eficácia, gerando recomenda- } \\
\text { ções que agreguem valor }\end{array}$ \\
\hline Gerentes - Empregados & $\begin{array}{l}\text { Empregados trabalhem para os gerentes com o } \\
\text { melhor de seus esforços, atendendo às expectati- } \\
\text { vas dos mesmos }\end{array}$ \\
\hline Gerentes - Fornecedores & $\begin{array}{l}\text { Fornecedores supram as necessidades de mate- } \\
\text { riais dos gerentes no momento necessário e nas } \\
\text { quantidades requisitadas }\end{array}$ \\
\hline
\end{tabular}

Fonte: Martinez (1998, p. 2) apud. Bianchi (2005). 
Jensen e Meckling (1976) observam que nenhum indivíduo pode desejar maximizar uma função que não seja a sua, pois o seu comportamento está fundamentado no conjunto de suas preferências e em seus objetivos. Assim, o agente e o principal são pessoas diferentes e os seus interesses nem sempre estão alinhados, o que resulta no chamado conflito de agência ou problema da relação agente-principal. Essa incoerência entre o comportamento desejado pelo principal e o apresentado pelo agente existe, segundo os autores, em todas as atividades de cooperação entre indivíduos.

Verifica-se que tais conflitos de interesse conduzem à existência de custos, que envolvem os gastos para monitoramento e controle do comportamento dos agentes ou administradores. Jensen e Meckling (1976) ainda definem custos de agência como a soma de três elementos:

a) Despesas de monitoramento por parte do principal.

b) Despesas de ligação por parte do agente. Seriam as despesas relacionadas a garantir que o agente não prejudicará o principal com as suas ações, ou assegurar uma compensação ao principal, caso ele tome tais ações.

c) A perda residual. Refere-se aos custos relacionados à perda de bemestar devido às divergências entre principal e agente, conforme abordado anteriormente.

Bianchi e Nascimento (2005) relatam que o custo de agência está associado à ineficiência nas relações entre o principal e o agente e representa um custo de transação de acentuada importância na análise de estruturas organizacionais. Nesse sentido, Jensen e Meckling (1976) dizem que os custos de agência estão presentes nos contratos e na capacidade das pessoas em estabelecer os contratos. Esses contratos podem se dar de forma simples ou sofisticada, conforme a natureza da transação entre as partes e os incentivos para o seu cumprimento. Andrade e Rossetti (2004) acrescentam que, se os contratos forem incompletos e os comportamentos imperfeitos, abre-se espaço para o desalinhamento entre os interesses dos gestores e dos acionistas. E, dessa forma, os conflitos dificilmente serão evitados e os seus efeitos conduzirão à geração dos custos de agência.

O desempenho do agente dificilmente será monitorado perfeitamente pelo principal, uma vez que, por ele estar diretamente envolvido com a execução das atribuições, possuirá mais informações sobre a situação do que o principal. Assim, o problema da relação agente-principal sofre grande influência e se inicia quando houver essa assimetria de informações.

A assimetria de informações pode ser caracterizada como uma situação na qual uma das partes da transação não possui toda a informação relevante 
necessária para averiguar se os termos do contrato, que está sendo proposto, são mutuamente aceitáveis e se serão implementados. Por isso, essa assimetria pode resultar em falhas de mercado. O exemplo clássico da literatura é o "mercado de limões" de Akerlof (1970).

A teoria da agência considera que a informação disponível não é completa e que há custos em coletá-la. Dessa forma, a relação entre principal e agente é de assimetria de informações, tendo o agente uma informação de que o principal não dispõe. Essa relação introduz dois tipos de problemas transacionais relevantes para a decisão sobre o modo como devem se organizar as empresas e suas relações com fornecedores e clientes: o problema da seleção adversa e do risco moral.

No caso de seleção adversa, o agente envolvido tem mais informações sobre as suas particularidades que a outra parte, o que consiste na possibilidade de oportunismo que precede o estabelecimento do contrato. No mercado de saúde suplementar, por exemplo, a seleção adversa pode ocorrer nos dois lados da relação, conforme argumentam Delgado e Campos (2012). De um lado, o cliente pode não fornecer todas as informações de sua saúde, o que dificulta o cálculo adequado do prêmio do plano de saúde por parte da operadora. Do outro lado, as operadoras podem selecionar seus clientes para uma carteira de risco superior, com maior probabilidade de utilização e mais cara.

Quanto ao risco moral, ele se dá após o fechamento do contrato, em geral quando as ações de uma parte não podem ser observadas por outra, o que permite que o agente faça uso de sua informação privada em benefício próprio, podendo trazer prejuízos ao principal durante a relação contratual. Um exemplo comumente citado na literatura é a possibilidade de que o comportamento individual possa ser alterado após a contratação do seguro. Nesse caso, a parte segurada pode agir de um modo menos cuidadoso, que aumente a probabilidade de um acidente ou dano ocorrer.

Dessa forma, a solução do problema de assimetria de informações consiste em obter um conjunto de incentivos e controles capazes de ajustar os interesses de ambos. O principal pode prover incentivos de modo que os agentes conduzam as ações à satisfação tanto dos seus interesses quanto dos interesses do próprio agente, para daí então monitorar os resultados.

Além dos programas de incentivos, a solução ou redução do problema agente-principal também deve passar pela aplicação de práticas de controle e monitoramento, conforme abordado anteriormente. Williamson (1985) cita que tais controles e incentivos são decorrentes do modelo de gestão organizacional, 
que estabelece a forma como a organização vai ser administrada. Eles atuam de forma a premiar ou punir seus gestores a partir de um processo que retrata quais serão os resultados e como devem ser alcançados.

Bianchi e Nascimento (2005) relatam que a área de controladoria pode contribuir com a teoria da agência no sentido de monitorar um sistema de informação, fomentar a transparência nas ações dos gestores, mensurar resultados e proporcionar feedback ao principal e aos agentes. Ela pode ser considerada, na visão dos autores, um mecanismo interno de governança corporativa, capaz de ampliar as possibilidades de redução da assimetria de informação e, por fim, minimizar os conflitos de interesse.

A perspectiva de análise dada para os custos invisíveis nesse estudo (sob o olhar das multas e juros) permite considerar a hipótese de que o comportamento dos agentes envolvidos em determinadas tarefas pode influenciar no surgimento de tais custos. Assim, na medida em que a execução de suas atribuições sofre desvios dos padrões estipulados pela organização, gastos desnecessários podem aparecer e causar impactos significativos.

Nesse ponto, a teoria da agência possibilita compreender, dentro da relação entre agente e principal, como se dão esses conflitos de interesses e as possíveis soluções para resolver ou minimizar o problema. A assimetria de informações, citada como grande causa para as ocorrências dos conflitos, também não pode ser descartada como fato importante para os custos invisíveis, uma vez que as partes envolvidas podem não deter todas as informações necessárias para a execução das atividades.

\section{Metodologia}

Por meio de estatística descritiva, demonstraremos que a Universidade de Brasília não registra adequadamente juros, multas e atualizações monetárias nas contas de energia elétrica e telefonia. Em vez de registrar os juros, multas e atualizações monetárias separadamente dos valores totais das contas, os gestores registram esses valores integralmente, como se essas contas não tivessem sido pagas em atraso, não sinalizando ao sistema a presença desses custos desnecessários e não indicando a necessidade de medidas nesse sentido.

O levantamento dos dados foi feito nos arquivos setoriais da Prefeitura do Campus (PRC), unidade responsável pela coordenação dos serviços de manutenção da UnB. Os documentos analisados são as respectivas faturas desses contratos 
de prestação de serviços, mais precisamente, as de energia elétrica emitidas pela Companhia Energética de Brasília (CEB) e as de telefonia fixa, pela Oi S.A. A coleta teve início em torno dessas faturas, principalmente pela representatividade que esses dados poderiam apresentar e por estarem localizados dentro de uma mesma unidade administrativa (Prefeitura do Campus - PRC), o que, apesar dos tramites burocráticos, facilitou o acesso em ambos os arquivos.

A gestão documental de tais faturas é recente, tanto por parte da Diretoria de Tecnologia (Ditec), responsável pela gestão da área de telefonia, quanto por parte da Coordenadoria de Manutenção e Instalação dos serviços de energia elétrica da UnB (CMI). Dessa maneira, os dados coletados e analisados correspondem aos anos de 2013 e 2014, cujos arquivos se encontravam mais completos. No entanto, pelo fato de terem sido identificadas algumas faturas referentes aos anos de $2010 \mathrm{e}$ 2012, essas foram incluídas e comporão, estatisticamente, apenas o montante final atribuído aos custos invisíveis. Não haverá, portanto, uma análise mais profunda para essa parte da amostra pela falta de alguns meses. Em relação aos anos anteriores, infelizmente não foram encontradas informações.

Também foram obtidas informações sobre os procedimentos de gestão das unidades envolvidas a fim de se entender o processo de pagamento das faturas e identificar os possíveis gargalos. Para isso, foram realizadas entrevistas com os gestores e colaboradores da Ditec, CMI e da Diretoria de Contabilidade e Finanças (DCF).

A título de esclarecimento para análise dos dados, os juros, multas e atualizações monetárias provenientes do atraso nos pagamentos são cobrados sempre na fatura do mês seguinte. Por exemplo, o valor de $\mathrm{R} \$ 21.300,52$, relacionado às faturas do consumo de energia elétrica do mês de fevereiro de 2013 (Quadro 2), é proveniente das faturas do mês de janeiro, que, consequentemente, foram pagas após o vencimento.

Com relação às faturas do mês de dezembro, apesar de o vencimento ocorrer em janeiro do ano seguinte, seu pagamento se dá com base no orçamento anterior, ou seja, no ano em que se deu o consumo. É liquidada, portanto, como restos a pagar do exercício anterior. Tal raciocínio também se faz para as contas de telefone que serão analisadas mais adiante.

Nesse sentido, há que se observar que, por meio da coleta manual que foi realizada e pelos dados disponibilizados para esta pesquisa, não foi possível identificar quando ocorreu o pagamento de cada fatura e há quanto tempo estava em atraso. 


\section{Resultados}

\section{Energia elétrica}

De modo a permitir uma melhor visualização e interpretação dos dados nas respectivas relações temporais, os resultados referentes aos juros, multas e atualizações foram agrupados em quadros, conforme os anos e meses de cada tipo de serviço. Para evitar repetições da expressão "juros, multas e atualizações monetárias", a sigla JMA será utilizada nas próximas designações.

Quadro 2 - Faturas de energia elétrica - CEB - 2013

\begin{tabular}{|c|c|c|c|c|c|c|c|}
\hline $\begin{array}{l}\text { Mês de } \\
\text { consumo }\end{array}$ & Venc. & $\begin{array}{l}\text { Valor total } \\
\text { das faturas } \\
\text { (R\$) }\end{array}$ & $\begin{array}{l}\text { № de faturas } \\
\text { com juros/ } \\
\text { multas }\end{array}$ & $\begin{array}{l}\text { Total de } \\
\text { multas / } \\
\text { juros (R\$) }\end{array}$ & $\begin{array}{l}\text { № de } \\
\text { fatu- } \\
\text { ras } \\
\text { sem } \\
\text { juros/ } \\
\text { multas }\end{array}$ & $\begin{array}{l}\text { Total } \\
\text { de } \\
\text { fatu- } \\
\text { ras }\end{array}$ & $\begin{array}{l}\text { \% de } \\
\text { faturas } \\
\text { com } \\
\text { juros/ } \\
\text { multas }\end{array}$ \\
\hline Janeiro & $20 / 02 / 2013$ & $632.664,44$ & 5 & 33,59 & 14 & 19 & $26,32 \%$ \\
\hline Fevereiro & $20 / 03 / 2013$ & $433.682,38$ & 103 & $21.300,52$ & 75 & 178 & $57,87 \%$ \\
\hline Março & $20 / 04 / 2013$ & $562.659,91$ & 100 & $6.551,18$ & 82 & 182 & $54,95 \%$ \\
\hline Abril & $20 / 05 / 2013$ & $548.244,39$ & 148 & $2.400,14$ & 36 & 184 & $80,43 \%$ \\
\hline Maio & $20 / 06 / 2013$ & $566.419,27$ & 1 & 29,18 & 187 & 188 & $0,53 \%$ \\
\hline Junho & 20/07/2013 & $536.455,90$ & 2 & 2,09 & 19 & 21 & $9,52 \%$ \\
\hline Julho & 20/08/2013 & $589.736,55$ & 18 & 419,48 & 241 & 259 & $6,95 \%$ \\
\hline Agosto & 20/09/2013 & $489.228,41$ & 19 & 60,47 & 104 & 123 & $15,45 \%$ \\
\hline Setembro & $20 / 10 / 2013$ & $603.832,02$ & 18 & 115,33 & 103 & 121 & $14,88 \%$ \\
\hline Outubro & $20 / 11 / 2013$ & $636.869,92$ & 6 & 940,82 & 57 & 63 & $9,52 \%$ \\
\hline Novembro & $20 / 12 / 2013$ & $598.324,13$ & 7 & $3.132,19$ & 2 & 9 & $77,78 \%$ \\
\hline Dezembro & $20 / 01 / 2014$ & $621.098,54$ & 87 & $1.243,94$ & 31 & 118 & $73,73 \%$ \\
\hline TOTAL & & $6.819 .215,86$ & 514 & $36.228,93$ & 952 & 1465 & \\
\hline Média & & & 42,83333333 & & & & \\
\hline
\end{tabular}

Fonte: Elaboração própria.

Conforme mencionado, os documentos não foram arquivados em sua totalidade pelos setores responsáveis, portanto, observa-se que, em relação aos meses de 2013 (Quadro 02), houve uma diferença considerável no número de faturas de 
energia elétrica analisadas. Para o mês de novembro, por exemplo, apenas nove faturas foram encontradas, enquanto em maio foram 188.

Considerando ainda os dados apresentados no Quadro 2, verifica-se que, do

Gráfico 1 - Percentual de faturas de energia elétrica com/sem JMA - ano 2013

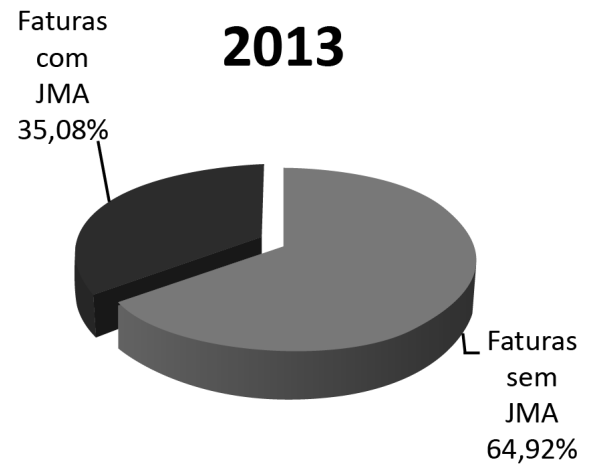

Fonte: Elaboração própria.

\section{Gráfico 2 - Percentual de faturas de energia elétrica com/sem JMA - ano 2014}

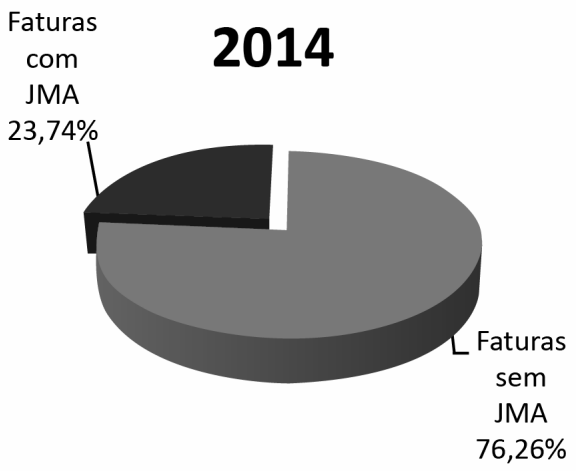

Fonte: Elaboração própria.

total de faturas de energia elétrica de 2013 analisadas (1.465), 35,08\% delas tinham em sua composição juros, multas e/ou atualizações monetárias. Ou seja, elas foram pagas apresentando os respectivos custos, o que representa, em média, 42,83 faturas por mês nessa situação. Assim, apurou-se um total de R\$ 36.228,93 em juros, multas e/ou atualizações monetárias para o ano de 2013.

Comparando essas informações do Quadro 2, referente ao ano de 2103, com os dados do Quadro 3, referentes ao ano de 2014, verifica-se uma queda no percentual de faturas de energia elétrica com JMA, de 35,08\% para $23,74 \%$, e uma média de 19,66 faturas por mês com JMA para o ano de 2014. A comparação entre o percentual de faturas com JMA em 2013 e 2014 pode ser observada por meio dos Gráficos 1 e 2.

Quadro 3 - Faturas de Energia elétrica - CEB - 2014

\begin{tabular}{|l|l|l|l|l|l|l|l|}
\hline $\begin{array}{l}\text { Mês de } \\
\text { consumo }\end{array}$ & Venc. & $\begin{array}{l}\text { Valor total } \\
\text { das faturas } \\
\text { (R\$̦) }\end{array}$ & $\begin{array}{l}\text { No de faturas } \\
\text { com JMA }\end{array}$ & $\begin{array}{l}\text { Total de } \\
\text { JMA (R\$) }\end{array}$ & $\begin{array}{l}\text { No } \\
\text { de } \\
\text { fatu- } \\
\text { ras } \\
\text { sem } \\
\text { JMA }\end{array}$ & $\begin{array}{l}\text { Total } \\
\text { de } \\
\text { fatu- } \\
\text { ras }\end{array}$ & \begin{tabular}{l}
$\begin{array}{l}\text { de } \\
\text { faturas } \\
\text { com } \\
\text { JMA }\end{array}$ \\
\hline Janeiro
\end{tabular} \\
\hline Fevereiro & $20 / 02 / 2014$ & $507.936,87$ & 12 & 958,27 & 10 & 22 & $54,55 \%$ \\
\hline Março & $20 / 04 / 2014$ & $119.987,53$ & 16 & $1.018,60$ & 104 & 120 & $13,33 \%$ \\
\hline
\end{tabular}




\begin{tabular}{|l|l|l|l|l|l|l|l|}
\hline Abril & $20 / 05 / 2014$ & $526.832,43$ & 0 & - & 10 & 10 & $0,00 \%$ \\
\hline Maio & $20 / 06 / 2014$ & $109.455,85$ & 8 & $1.349,20$ & 104 & 112 & $7,14 \%$ \\
\hline Junho & $20 / 07 / 2014$ & $625.918,81$ & 99 & 882,90 & 18 & 117 & $84,62 \%$ \\
\hline Julho & $20 / 08 / 2014$ & $568.613,24$ & 18 & $14.373,87$ & 99 & 117 & $15,38 \%$ \\
\hline Agosto & $20 / 09 / 2014$ & $519.134,18$ & 3 & $1.481,33$ & 8 & 11 & $27,27 \%$ \\
\hline Setembro & $20 / 10 / 2014$ & $744.550,76$ & 4 & 783,67 & 117 & 121 & $3,31 \%$ \\
\hline Outubro & $20 / 11 / 2014$ & $835.689,11$ & 5 & 602,09 & 23 & 28 & $17,86 \%$ \\
\hline Novembro & $20 / 12 / 2014$ & $903.041,35$ & 9 & $1.995,87$ & 96 & 105 & $8,57 \%$ \\
\hline Dezembro & $20 / 01 / 2015$ & $781.590,28$ & 44 & 866,84 & 71 & 115 & $38,26 \%$ \\
\hline TOTAL & & $\mathbf{6 . 8 6 1 . 8 6 0 , 7 6}$ & $\mathbf{2 3 6}$ & $\mathbf{1 4 4 . 4 6 6 , 0 0}$ & $\mathbf{7 5 8}$ & $\mathbf{9 9 4}$ & \\
\hline Média & & & $\mathbf{1 9 , 6 6 6 6 6 6 6 7}$ & & & & \\
\hline
\end{tabular}

Fonte: Elaboração própria.

Entretanto, mesmo com a evidência de queda no percentual de faturas de energia elétrica que apresentaram JMA, o montante final apurado aumentou 298,75\% em relação ao ano de 2013 (Quadro 2), com um total de R\$ 144.466,00 de JMA em 2014, conforme Quadro 3. Entende-se, desse modo, que um maior percentual de faturas com JMA não é condição suficiente para um maior montante, tendo em vista a grande variação nos valores das contas. Assim, para uma visão mais ampla de como vem ocorrendo esse fenômeno no decorrer do tempo, o Gráfico 3 apresenta uma projeção do percentual de faturas com JMA para os anos de 2013 e 2014, tomando como base os dados dos Quadros 2 e 3.

\section{Gráfico 3 - Projeção das faturas com JMA - energia elétrica - 2013 e 2014}

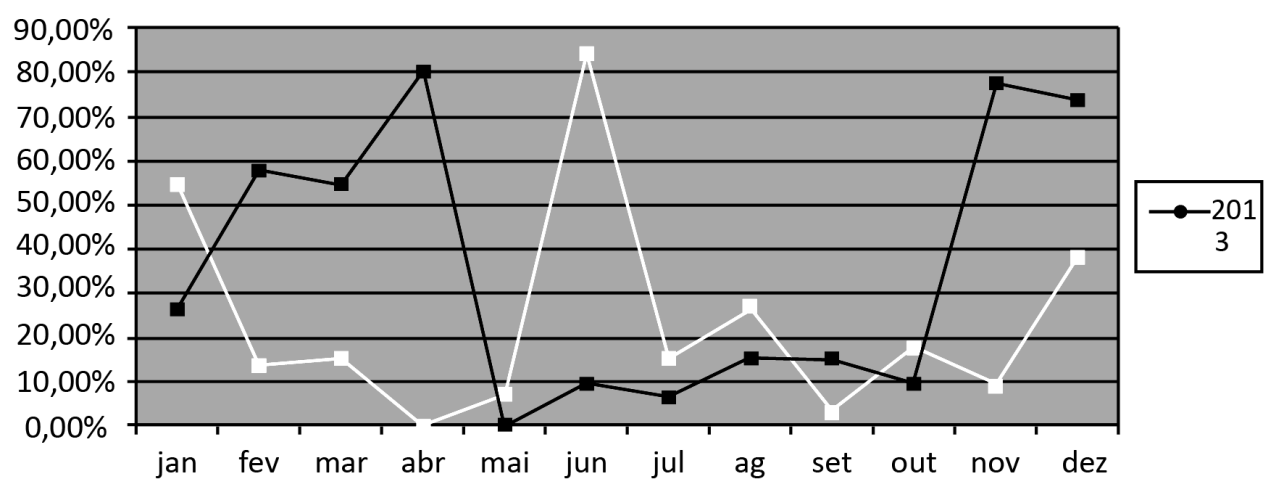

Fonte: Elaboração própria.

Por meio do Gráfico 3, é possível verificar que, para o ano de 2013, os meses de fevereiro, março e abril são os que apresentaram maiores percentuais de faturas 
com JMA, coincidindo com o período de férias acadêmicas². Já nos demais meses desse mesmo ano, os números estão mais estáveis no ponto abaixo de $20 \%$, com um pico maior em novembro e dezembro. O mesmo não se repete em 2014, quando as maiores taxas ocorreram nos meses de janeiro, junho e também em dezembro. Observa-se que, tanto em 2013 quanto em 2014, as férias acadêmicas parecem afetar o comportamento do pagamento das faturas, uma vez que a fatura de janeiro deve ser paga no mês seguinte, o que implica que as faturas de janeiro, junho e dezembro de 2014 também recaíram sobre meses de férias.

Ao término da análise das faturas de energia elétrica de 2013 e 2014 (Quadro 2 e 3), apresenta-se o montante final de $\mathrm{R} \$ 180.694,93$ em juros, multas e atualizações monetárias.

Durante a fase de coleta desses dados, também foi possível identificar e realizar um breve mapeamento referente ao processo de pagamento dessas faturas. Em entrevista $^{3}$, o gestor da $\mathrm{CMI}$, responsável pelo atesto, argumenta que as faturas recebidas são encaminhadas ao Gabinete da PRC, para os procedimentos de pagamento, entre 5 e 10 dias do vencimento, na pior das hipóteses. Posteriormente são encaminhadas para o Decanato de Planejamento e Orçamento (DPO), para alocação dos recursos; e Diretoria de Contabilidade e Finanças (DCF), para execução dos pagamentos.

Mediante análise junto ao sistema de controle e trâmite de documentos (o sistema $U_{n B D o c}^{4}$ ), foi possível destacar, por meio de uma simples amostra de 12 processos, que $66,66 \%$ atrasaram dentro da própria DCF e $16.66 \%$ dentro do Decanato de Planejamento e Orçamento (DPO). Entretanto, 33,33\% dos processos dessa amostra tramitaram por mais de sete dias dentro do gabinete da PRC. Esse tempo despendido no gabinete da PRC também pode ser um fator importante para desencadear o atraso nas demais unidades (DPO e DCF).

\section{Telefonia}

Foi realizada também a coleta de dados referentes às faturas dos serviços de telefonia fixa, prestados pela empresa Oi/S.A, conforme pode ser observado no Quadro 4.

\section{Quadro 4 - Faturas de telefonia fixa - Oi - 2013}

\footnotetext{
2 Devido à greve ocorrida na universidade em 2012, no ano de 2013 as férias ocorreram nos meses de março-abril; julho-agosto; dezembro.

${ }^{3}$ As entrevistas foram realizadas sem roteiro específico, com perguntas gerais para que os entrevistados indicassem os principais pontos que considerassem importantes no processo.

${ }^{4}$ Sistema de tramitação interna de documentos da universidade.
} 


\begin{tabular}{|l|l|l|l|l|l|l|l|}
\hline $\begin{array}{l}\text { Mês de } \\
\text { consumo }\end{array}$ & Venc. & $\begin{array}{l}\text { Valor total } \\
\text { das faturas } \\
\text { (R\$) }\end{array}$ & $\begin{array}{l}\text { No de } \\
\text { faturas com } \\
\text { JMA }\end{array}$ & $\begin{array}{l}\text { Total de } \\
\text { JMA (R\$) }\end{array}$ & $\begin{array}{l}\text { No de } \\
\text { faturas } \\
\text { sem } \\
\text { JMA }\end{array}$ & $\begin{array}{l}\text { Total } \\
\text { de } \\
\text { faturas }\end{array}$ & $\begin{array}{l}\text { \% de } \\
\text { faturas } \\
\text { com } \\
\text { JMA }\end{array}$ \\
\hline Janeiro & $20 / 02 / 2013$ & $108.198,68$ & 1056 & $1.056,00$ & 450 & 1506 & $70,12 \%$ \\
\hline Fevereiro & $20 / 03 / 2013$ & $145.556,00$ & 431 & 607,24 & 2322 & 2753 & $15,66 \%$ \\
\hline Março & $20 / 04 / 2013$ & $69.023,12$ & 1222 & $1.360,62$ & 553 & 1775 & $68,85 \%$ \\
\hline Abril & $20 / 05 / 2013$ & $48.265,30$ & 7 & 163,16 & 720 & 727 & $0,96 \%$ \\
\hline Maio & $20 / 06 / 2013$ & $179.904,88$ & 312 & $1.450,72$ & 2719 & 3031 & $10,29 \%$ \\
\hline Junho & $20 / 07 / 2013$ & $169.761,42$ & 242 & $2.265,13$ & 2735 & 2977 & $8,13 \%$ \\
\hline Julho & $20 / 08 / 2013$ & $183.178,08$ & 2531 & $3.538,10$ & 532 & 3063 & $82,63 \%$ \\
\hline Agosto & $20 / 09 / 2013$ & $178.618,42$ & 223 & 334,91 & 2685 & 2908 & $7,67 \%$ \\
\hline Setembro & $20 / 10 / 2013$ & $174.711,58$ & 1 & 2,14 & 2962 & 2963 & $0,03 \%$ \\
\hline Outubro & $20 / 11 / 2013$ & $180.579,22$ & 2692 & $9.019,46$ & 420 & 3112 & $86,50 \%$ \\
\hline Novembro & $20 / 12 / 2013$ & $163.373,78$ & 6 & 14,49 & 2687 & 2693 & $0,22 \%$ \\
\hline Dezembro & $20 / 01 / 2014$ & $167.098,22$ & 2463 & $3.202,21$ & 531 & 2994 & $82,26 \%$ \\
\hline TOTAL & & $1.768 .268,70$ & 11.186 & $23.014,18$ & 19.316 & 30.502 & \\
\hline Média & & & 932,166667 & & & & \\
\hline Fonte: Ela & & & & & & \\
\hline
\end{tabular}

Fonte: Elaboração própria.

Assim como identificado nas faturas de energia elétrica, os documentos referentes às de telefonia fixa também não foram arquivados em sua totalidade pelo setor responsável. Portanto, também há uma variação no número de faturas em relação aos meses, que se estabiliza, um pouco, com a adoção do arquivo digital em meados de 2013. Identificou-se que, a partir desse período, a Oi/S.A passou a enviar as faturas tanto impressas quanto em meio digital, o que favoreceu um melhor controle desses documentos.

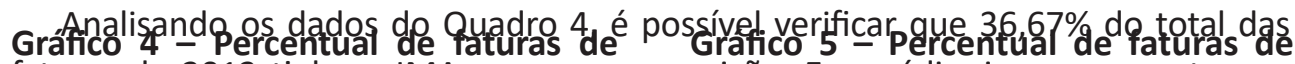
fatukas de 2013 tinham JMA em sua composicão Em média, isso representa que 232.16 faturas de telefone, por mês, foram pagas appresentando esses custos. Assim, 0

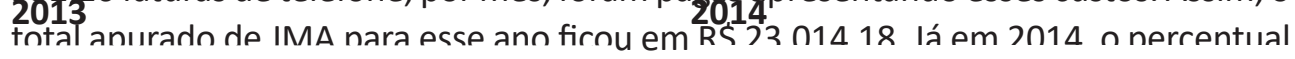

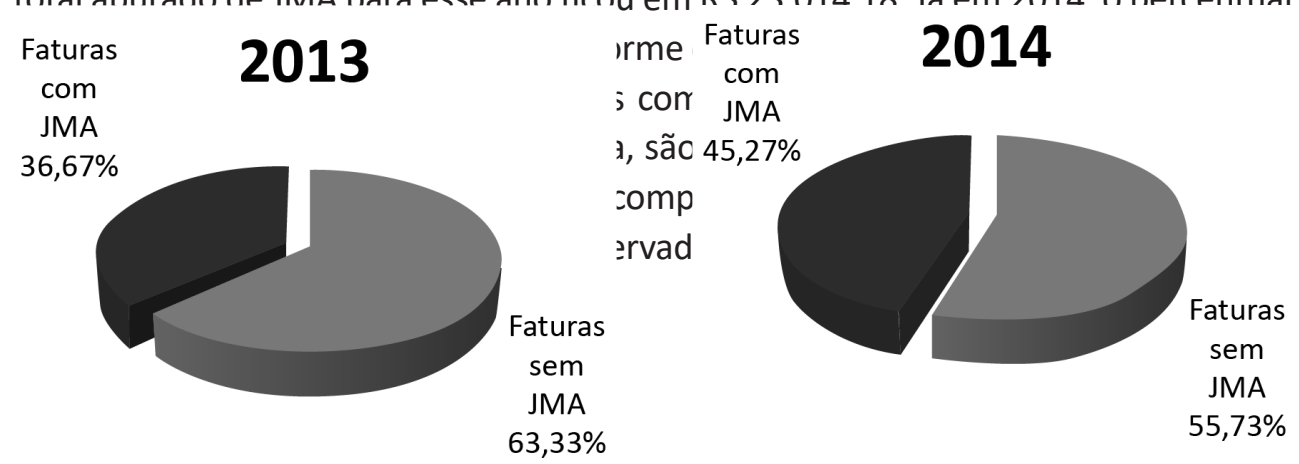

Fonte: Elaboração própria.

Fonte: Elaboração própria. 
Quadro 5 - Faturas de telefonia fixa - Oi - 2014

\begin{tabular}{|c|c|c|c|c|c|c|c|}
\hline $\begin{array}{l}\text { Mês de } \\
\text { consumo }\end{array}$ & Vencimento & $\begin{array}{l}\text { Valor total } \\
\text { das faturas } \\
\text { (R\$) }\end{array}$ & $\begin{array}{l}\text { № fatu- } \\
\text { ras com } \\
\text { juros/ } \\
\text { multas }\end{array}$ & $\begin{array}{l}\text { Total de } \\
\text { multas / } \\
\text { juros (R\$) }\end{array}$ & $\begin{array}{l}\text { No de } \\
\text { faturas } \\
\text { sem } \\
\text { juros/ } \\
\text { multas }\end{array}$ & $\begin{array}{l}\text { Total } \\
\text { de } \\
\text { faturas }\end{array}$ & $\begin{array}{l}\text { \% de } \\
\text { faturas } \\
\text { com } \\
\text { juros/ } \\
\text { multas }\end{array}$ \\
\hline Janeiro & $20 / 02 / 2014$ & $112.733,59$ & 0 & - & 2359 & 2359 & $0,00 \%$ \\
\hline Fevereiro & $20 / 03 / 2014$ & $143.424,03$ & 0 & - & 2549 & 2549 & $0,00 \%$ \\
\hline Março & $20 / 04 / 2014$ & $124.185,45$ & 211 & $1.246,04$ & 2358 & 2569 & $8,21 \%$ \\
\hline Abril & $20 / 05 / 2014$ & $157.900,37$ & 2442 & $5.463,32$ & 424 & 2866 & $85,21 \%$ \\
\hline Maio & $20 / 06 / 2014$ & $113.243,02$ & 2156 & $2.801,39$ & 376 & 2532 & $85,15 \%$ \\
\hline Junho & 20/07/2014 & $124.244,86$ & 2249 & $3.395,64$ & 193 & 2442 & $92,10 \%$ \\
\hline Julho & $20 / 08 / 2014$ & $102.514,01$ & 2078 & $2.967,49$ & 298 & 2376 & $87,46 \%$ \\
\hline Agosto & 20/09/2014 & $108.164,73$ & 2088 & $3.003,80$ & 246 & 2334 & $89,46 \%$ \\
\hline Setembro & $20 / 10 / 2014$ & $97.206,14$ & 2064 & $2.169,34$ & 391 & 2455 & $84,07 \%$ \\
\hline Outubro & $20 / 11 / 2014$ & $138.873,54$ & 0 & - & 2501 & 2501 & $0,00 \%$ \\
\hline Novembro & $20 / 12 / 2014$ & $119.530,68$ & 0 & - & 2440 & 2440 & $0,00 \%$ \\
\hline Dezembro & $20 / 01 / 2015$ & $115.075,14$ & 268 & 359,76 & 2254 & 2522 & $10,63 \%$ \\
\hline TOTAL & & $1.457 .095,56$ & 13.556 & $21.406,78$ & 16.389 & 29.945 & \\
\hline Média & & & 1129,667 & & & & \\
\hline
\end{tabular}

Fonte: Elaboração própria.

Apesar desse aumento no número de faturas com os citados custos, o valor total de $\mathrm{R} \$ 21.406,78$ em JMA, para o ano de 2014, foi 7,50\% menor em comparação ao obtido no ano de 2013 (Quadro 4). Dessa maneira, houve uma pequena redução no desperdício de recursos financeiros.

Há que observar que, mesmo ocorrendo um gasto menor com JMA, o controle relativo a todo processo de pagamento dessas faturas regrediu, uma vez que o percentual de faturas com JMA aumentou. Quanto a isso, os gestores da Ditec relatam que nem todas as faturas são enviadas pela Oi/S.A e que sempre as encaminham com antecedência para os procedimentos de pagamento.

Por meio do Gráfico 6, é possível analisar, ao longo dos meses, o comportamento das faturas de telefone fixo que apresentaram JMA, sob o olhar comparativo dos dois anos em questão (Quadros 4 e 5 ). 


\section{Gráfico 6 - Projeção das faturas com JMA - telefonia fixa - 2013 e 2014}

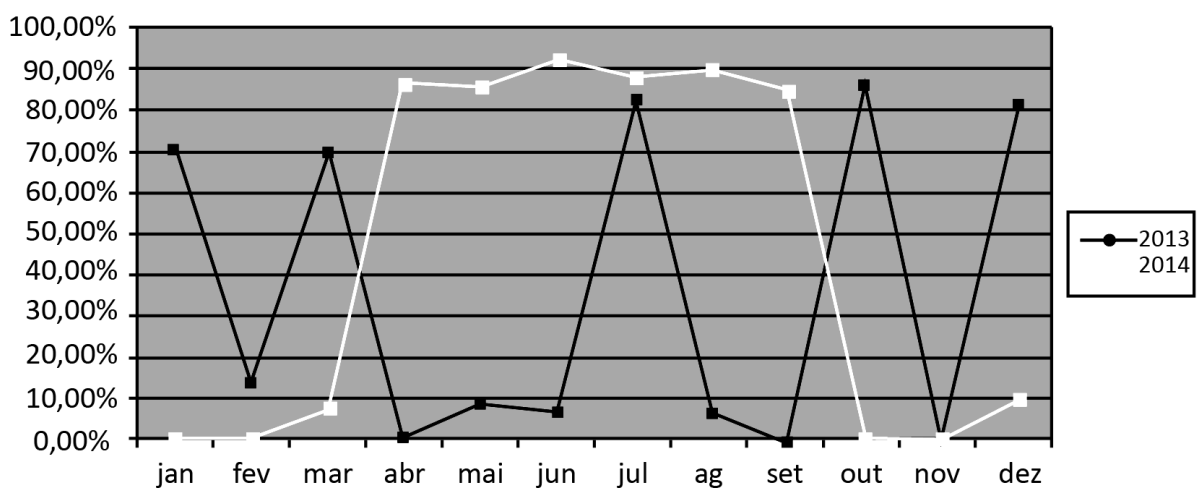

Fonte: Elaboração própria.

A constante variação percentual de faturas com JMA que ocorreu entre os meses de 2013 confirma a necessidade de um melhor controle, para que, dada a devida importância, os pagamentos ocorram sem atrasos. Essa oscilação nos percentuais retrata uma falha na gestão processual maior até do que a identificada nas faturas de energia elétrica (Gráfico 1). Observa-se forte volatilidade no comportamento, sem um aparente equilíbrio. Assim, não houve, segundo os dados, um esforço contínuo entre os meses para minimizar o fato.

Já em 2014, notam-se dois momentos bem distintos nos percentuais: um em que os índices ficaram em torno dos $10 \%$ e outro em que eles ultrapassaram a barreira dos $80 \%$. O que chama a atenção nesse último dado é o alto índice de faturas sendo pagas em atraso numa sequência de seis meses, de abril a setembro de 2013.

Há que se destacar nessa sequência o mês de junho, que apresentou um pico de 92,10\% de faturas com JMA. Desse modo, apenas 7,9\% das faturas desse mês não tinham histórico de atrasos no pagamento. No entanto, nos outros seis meses de 2014, há situações em que os índices chegaram 0,00\%, como nos meses de janeiro e fevereiro, outubro e novembro. Ou seja, nenhuma fatura apresentou JMA em sua composição nesses períodos, o que demonstra ser possível uma boa gestão em torno desse problema.

Referente ao processo de pagamento dessas faturas, o breve mapeamento realizado junto ao sistema UnBDoc, também com uma amostra de 12 processos, apontou que $50 \%$ deles atrasaram dentro da Diretoria de Contabilidade de Finanças (DCF) e 16,66\%, dentro do Decanato de Planejamento e Orçamento (DPO). Já dentro do Gabinete da PRC, $25 \%$ dos processos dessa amostra tramitaram por mais de sete dias para os devidos encaminhamentos.

Portanto, os processos referentes aos pagamentos das faturas de telefonia fixa sofrem também o mesmo gargalo dos processos referentes às faturas de energia 
elétrica, o que reforça a ideia de que o tempo despendido no trâmite interno desses departamentos pode ser um importante elemento de análise para a melhor gestão desses custos invisíveis.

O Quadro 6 apresenta em detalhes o somatório final de JMA. Observa-se nele a inserção dos valores referentes ao ano de 2010 e o mês de dezembro de 2012, como abordado no início desta seção. As informações referentes a essas duas amostras podem ser vistas em anexo.

\section{Quadro 6 - Total de JMA - faturas de energia elétrica e telefonia fixa}

\begin{tabular}{|l|l|l|l|}
\hline Período & Energia Elétrica (R\$) & Telefonia Fixa (R\$) & TOTAL DE JMA \\
\hline 2010 & $41.687,9$ & - & $41.687,9$ \\
\hline $\begin{array}{l}\text { Dezembro } \\
-2012\end{array}$ & - & $3.624,25$ & $3.624,25$ \\
\hline 2013 & $36.228,93$ & $23.014,18$ & $59.243,11$ \\
\hline 2014 & $144.466,00$ & $21.406,78$ & $165.872,78$ \\
\hline TOTAL & $\mathbf{2 2 2 . 3 8 2 , 8 3}$ & $\mathbf{4 8 . 0 4 5 , 2 1}$ & $\mathbf{2 7 0 . 4 2 8 , 0 4}$ \\
\hline
\end{tabular}

Fonte: Elaboração própria.

Como balanço final, foi possível identificar, por meio da soma dos montantes parciais, presentes nas faturas de energia elétrica e de telefonia fixa, o total de $\mathrm{R} \$ 270.428,04$ em JMA. Tal valor refere-se, portanto, à expressão numérica dos custos invisíveis, conforme proposto neste estudo.

\section{Impacto orçamentário}

Após a comprovação e quantificação desses custos invisíveis, é importante, dentro do aspecto da gestão econômica dos gastos públicos, demonstrar a sua representatividade orçamentária e como os gastos poderiam ser mais bem aproveitados numa condição alternativa.

Sabe-se que os recursos orçamentários providos pela União não são suficientes para a execução financeira da Universidade e que uma melhor gestão dos gastos, incluindo os invisíveis, se encaixa perfeitamente dentro das medidas de sustentabilidade necessárias.

Assim, uma vez que tais custos não são identificados ou previstos pelos sistemas de controle da Universidade, não se tem um número exato do quanto esses valores poderiam ajudar no equilíbrio das contas internas. Portanto, o que se apresenta aqui, em termos quantitativos, é uma amostra, que, se somada a outras, pode resultar em algo ainda muito mais relevante para o aspecto financeiro. 
Nesse sentido, considerando os recursos da UnB, a Lei Orçamentária Anual (LOA) no 12.952/2014 disponibilizou um orçamento da ordem de $\mathrm{R} \$ 1,57$ bilhão para o ano de 2014, sendo $\mathrm{R} \$ 1,17$ bilhão da fonte de recursos do Tesouro $(74,7 \%), R \$ 386,7$ milhões da fonte de recursos próprios $(24,5 \%)$ e $\mathrm{R} \$ 12,6$ milhões provenientes de rendimentos de aplicação financeira $(0,8 \%)$. Uma parcela significativa desses recursos (R\$ 954 milhões) é destinada para pagamento de pessoas e encargos sociais, o que compromete mais de $80 \%$ da dotação. A outra parcela destina-se às despesas de custeio da universidade ( $R \$ 154,5$ milhões), responsável pela manutenção das atividades institucionais e $\mathrm{R} \$ 67,5$ milhões, para as despesas de capital - como aos Programas de Assistência ao Estudante de Ensino Superior (PNAES).

Ao tomar como base os recursos destinados às despesas de custeio da UnB para o ano de 2014 ( $R \$ 154,5$ milhões), verifica-se que aproximadamente $0,11 \%$ desse valor foram desperdiçados com juros, multas e atualizações monetárias, ou seja, $\mathrm{R} \$ 165.872,78$, conforme o Quadro 6. Esse montante de JMA apurado no ano de 2014 pode ser considerado de grande relevância, principalmente pela dificuldade financeira que a instituição apresenta para garantir a execução do planejamento e desenvolvimento das suas atividades. Prova disso é que, no ano de 2014 , quase $90 \%{ }^{5}$ de toda a receita própria, arrecadada pelas unidades acadêmicas e administrativas, estavam previstos para reforçar o atendimento das despesas de custeio.

Além disso, esses valores de JMA representam também um gasto que poderia ser melhor aproveitado numa situação alternativa. Como, por exemplo, investimento em laboratórios de pesquisa, equipamentos de informática, reforma de salas de aula etc. Ou, ainda, é possível questionar: que ganhos a universidade poderia ter se esses custos não existissem? Com certeza alguma área teria um fôlego a mais para execução das suas operações.

Considerando essa análise orçamentária, sob a perspectiva dos recursos das unidades acadêmicas, é possível visualizar que o impacto de custos invisíveis nas contas seria ainda maior. Sendo assim, identificou-se, como pode ser visto no Quadro 7, que algumas dessas unidades possuem uma dotação financeira inferior ao que se gastou com JMA aqui apresentados. São, portanto, quatro unidades acadêmicas, se considerado o montante de JMA apurado em 2014 (R\$165.872,78 Quadro 6). Ou seja, elas não receberam sequer tal valor para o desenvolvimento de suas atividades durante o ano.

\footnotetext{
${ }^{5}$ Dado obtido no Planejamento e Desenvolvimento Institucional (PDI) - UnB 2014-2017. Disponível em: <http:// www.dpo.unb.br/documentos/PDI/PDI_2014-2017.pdf>.
} 
Quadro 7 - Matriz distribuição orçamentária - 2013 e 2014

\begin{tabular}{|c|c|c|c|c|}
\hline Instituto/Faculdade & $\begin{array}{l}\text { Recursos - } \\
2013(R \$)\end{array}$ & $\%$ & $\begin{array}{l}\text { Recursos - } \\
2014 \text { (R\$) }\end{array}$ & $\%$ \\
\hline Faculdade de Tecnologia (FT) & $359.193,21$ & 6,76 & $388.452,57$ & 6,94 \\
\hline Instituto de Exatas (IE) & $344.864,76$ & 6,49 & $355.443,29$ & 6,35 \\
\hline Instituto de Artes (IdA) & $295.717,74$ & 5,56 & $303.241,21$ & 5,42 \\
\hline Instituto de Biologia (IB) & $293.983,27$ & 5,53 & $321.352,87$ & 5,74 \\
\hline Faculdade de Ceilândia (FCE) & $271.713,39$ & 5,11 & $293.912,61$ & 5,25 \\
\hline Instituto de letras (IL) & $268.821,96$ & 5,06 & $271.880,39$ & 4,86 \\
\hline Faculdade de Saúde (FS) & $245.691,93$ & 4,62 & $292.272,41$ & 5,22 \\
\hline $\begin{array}{l}\text { Fac. Administração, } \\
\text { Contabilidade e Economia } \\
\text { (Face) }\end{array}$ & $234.744,48$ & 4,42 & $253.326,93$ & 4,53 \\
\hline Faculdade de Medicina (FM) & $233.066,63$ & 4,39 & $228.349,25$ & 4,08 \\
\hline Instituto de Humanas (IH) & $223.174,52$ & 4,20 & $244.642,60$ & 4,37 \\
\hline $\begin{array}{l}\text { Faculdade de Agronomia e } \\
\text { Veterinária (FAV) }\end{array}$ & $221.383,70$ & 4,17 & $193.942,58$ & 3,47 \\
\hline Faculdade do Gama (FGA) & $216.683,03$ & 4,08 & $204.992,14$ & 3,66 \\
\hline $\begin{array}{l}\text { Faculdade de Planaltina } \\
\text { (FUP) }\end{array}$ & $196.232,00$ & 3,69 & $199.456,15$ & 3,56 \\
\hline Faculdade de Educação (FE) & $188.939,16$ & 3,56 & $236.102,46$ & 4,22 \\
\hline Instituto de Química (IQ) & $180.838,90$ & 3,40 & $174.822,56$ & 3,12 \\
\hline Instituto de Física (IF) & $179.577,02$ & 3,38 & $182.641,98$ & 3,26 \\
\hline Instituto de Psicologia (IP) & $179.156,44$ & 3,37 & $195.936,14$ & 3,50 \\
\hline $\begin{array}{l}\text { Faculdade de Comunicação } \\
\text { (FAC) }\end{array}$ & $177.340,55$ & 3,34 & $185.716,84$ & 3,32 \\
\hline Instituto de Geociências (IG) & $155.234,89$ & 2,92 & $162.892,51$ & 2,91 \\
\hline $\begin{array}{l}\text { Faculdade de Arquitetura e } \\
\text { Urbanismo (FAU) }\end{array}$ & $145.920,47$ & 2,75 & $146.372,86$ & 2,62 \\
\hline $\begin{array}{l}\text { Faculdade de Educação } \\
\text { Física (FEF) }\end{array}$ & $145.007,19$ & 2,73 & $162.000,45$ & 2,89 \\
\hline Faculdade de Direito (FD) & $141.307,51$ & 2,66 & $166.198,51$ & 2,97 \\
\hline $\begin{array}{l}\text { Instituto de Ciências Sociais } \\
\text { (ICS) }\end{array}$ & $129.830,69$ & 2,44 & $121.440,61$ & 2,17 \\
\hline $\begin{array}{l}\text { Faculdade de Ciências da } \\
\text { Informação (FCl) }\end{array}$ & $113.762,01$ & 2,14 & $105.968,75$ & 1,89 \\
\hline $\begin{array}{l}\text { Instituto de Relações } \\
\text { Internacionais (Irel) }\end{array}$ & $88.195,60$ & 1,66 & $99.388,81$ & 1,78 \\
\hline $\begin{array}{l}\text { Instituto de Ciências Políticas } \\
\text { (Ipol) }\end{array}$ & $84.261,17$ & 1,59 & $105.698,53$ & 1,89 \\
\hline TOTAL & $5.314 .642,23$ & 100,00 & $5.596 .446,00$ & 100,00 \\
\hline
\end{tabular}

Fonte: Orçamento do Programa Interno (OPI) - UnB. 
Já quando em comparação aos recursos distribuídos em 2013, o total de JMA referente a esse mesmo ano ( $R \$ 59.243,11$ - Quadro 6) equivale a $50 \%$ do orçamento de pelo menos três unidades acadêmicas.

Essa perspectiva de análise se torna ainda mais interessante pelo fato de que a maioria das faculdades e institutos possui, sob sua administração, mais de um departamento. Por exemplo, se dividirmos os recursos orçamentários destinados à Faculdade de Administração, Contabilidade e Economia (Face) entre os seus departamentos, a representatividade dos custos invisíveis em questão seria ainda maior.

Entretanto, mesmo se tratando de despesas que são liquidadas de forma centralizada, nas contas de custeio da UnB, sua descentralização para as fontes de recursos dessas unidades, com os devidos ajustes financeiros necessários, poderia, talvez, trazer um maior incentivo para o controle desses pagamentos, por parte dos agentes.

Questionamos que, se o impacto desses custos fosse sentido diretamente pelos departamentos, as ações para evitar as cobranças de juros, multas e atualizações poderiam ser mais intensas.

\section{Gestão do problema e o enfoque na teoria da agência}

Ainda sob o aspecto da gestão desses gastos, é oportuno, além de identificar sua possível origem, apresentar uma discussão sobre as ações realizadas para contornar o problema e por que a situação parece não mudar.

Verificou-se que algumas medidas administrativas foram implantadas por parte dos setores responsáveis pela coordenação das atividades de energia elétrica e telefonia fixa. Entre elas, a fim de minimizar atrasos, eliminou-se a obrigatoriedade de recebimento das faturas por parte do setor de protocolo da Prefeitura do Campus. Assim, elas passaram a ser entregues, pela empresa prestadora dos serviços, diretamente às unidades correspondentes (CMI e Ditec).

Segundo relato dos gestores envolvidos, houve, com essa medida, um ganho de dias ante o prazo de vencimento para a realização dos procedimentos de controle e atesto. Para isso, em cada uma das duas unidades, há um agente designado a efetuar o registro das faturas a serem atestadas e identificar aquelas que não foram recebidas. Nesse ponto, ambos relatam que nem todas as faturas são enviadas pelo fornecedor. Porém, nenhuma atitude é realizada para resolver o problema, como, por exemplo, a solicitação de uma 2 a via.

A gestão documental dessas faturas é outro ponto que merece atenção. Falhas nesse processo resultaram em arquivos incompletos e isso se torna reflexo dos procedimentos de controle que eram realizados. 
Diante disso, a Ditec vem mantendo um controle também por meio de arquivos digitais e, de certo modo, isso favoreceu um melhor agrupamento dos dados de consumo junto às planilhas e gráficos. Logo, questiona-se o porquê de a CMI não se prover também das faturas em meio digital, assim, a informação chegaria de forma mais rápida e precisa. É possível que a falta de incentivos em reportar as falhas e apresentar soluções seja um dos motivos que bloqueiem o processo de melhoria.

Entretanto, foi identificado que o principal gargalo não está apenas nesses procedimentos iniciais, de recebimento e atesto das faturas. Conforme já mencionado, o entrave maior se apresenta nos trâmites internos da Diretoria de Contabilidade e Finanças (DCF) e no Decanato de Planejamento e Orçamento da UnB (DPO).

Grande parte dos processos, identificados no sistema UnBdoc, extrapola o vencimento das faturas dentro da própria DCF. Segundo essa diretoria, a insuficiência orçamentária no processo de alocação dos recursos é justamente um dos motivos para essa ocorrência. Por se tratar de gastos recorrentes e de alta previsibilidade, isso também constitui um problema de gestão na universidade.

Há que se observar que, além da falta de incentivos que motivem ações mais eficazes, o conflito de interesses entre o agente e o principal (instituição) é outra situação que agrava e dificulta ainda mais a solução do problema.

Assim, a forma como os gestores registram os pagamentos das faturas, sem a classificação adequada dos juros, multas e atualizações, acaba por tornar os gastos com JMA invisíveis. De tal maneira, as faturas são liquidadas como normais e não há como distinguir o que é efetivamente serviço e encargos por atrasos.

A falta de informações quanto ao correto lançamento e talvez o receio de possíveis penalizações fazem com que essas ações caminhem de encontro às recomendações contábeis ${ }^{6}$. Isso acaba gerando um conflito entre o interesse individual do agente e as boas práticas de gestão financeira de que a instituição necessita. Do ponto de vista individual, o agente teme a penalização pelo problema e prefere o menor custo de trabalho. Do ponto de vista da universidade, há a perda na ausência do registro da informação e na não tomada de medidas para sanar o problema.

Apesar de a situação ser um tanto complexa, pois, por vezes, o gestor está limitado pela falta de recursos, medidas de controle devem ser aplicadas sem o descarte das penalizações cabíveis, como, por exemplo, a devolução da quantia que lesa o erário. Nesse aspecto, mecanismos internos de governança podem

\footnotetext{
6 Registrar adequadamente os juros e multas nas contas contábeis específicas conforme cada situação, a saber: 3.3.90.36.41 (Multas Dedutíveis - PF); 3.3.90.36.42 (Juros); 3.3.90.39.35 (Multas Dedutíveis - PJ); 3.3.90.39.36 (Multas Indedutíveis); 3.3.90.39.37 (Juros à PJ) ou 3.3.90.92.50 (Multas e Juros). Disponível em: http://sistemas2. cgu.gov.br/relats/uploads/RA175607
} 
contribuir, no sentido de monitorar e fomentar a transparência em todo o processo de pagamentos.

Em conjunto a isso, políticas de incentivo também podem exercer grande influência na gestão desses custos, uma vez que potencializam e conduzem as ações do agente aos interesses do serviço público de modo geral.

\section{Considerações finais}

Por meio das informações apresentadas neste estudo, constata-se que os custos invisíveis podem ser perfeitamente identificados e precificados, e podem representar um gasto considerável quando contabilizados ao longo dos anos. Os valores apurados demonstram que uma maior atenção deve ser dispensada, tanto para o caso aqui identificado, quanto para outras situações de difícil mensuração. É importante deixar claro que, apesar de invisíveis, num primeiro momento, tratase de custos passíveis de serem controlados e que uma boa gestão pode implicar ganhos de eficiência financeira para a instituição.

Nesse sentido, eles não afetariam a decisão alocativa da organização-ou seja, não seriam invisíveis do ponto de vista econômico, apesar de poderem ser considerados custos invisíveis do ponto de vista contábil, seguindo, por exemplo, as definições de Lima (2001) ou a de Femenick (2005). Isso ocorre, pois estão contabilizados de alguma forma em seu orçamento. Em outras palavras, a precificação do serviço corresponde aos custos reais, apesar da ignorância dos agentes quanto à existência desses custos. A crítica feita aqui refere-se ao fato de esses custos não se tornarem explícitos: isso impede uma gestão mais eficaz e eficiente que eliminasse despesas desnecessárias.

É bem visto que o impacto financeiro aqui apresentado é de maior relevância quando considerado numa relação orçamentária entre as unidades acadêmicas do que em comparação à conta de custeio da UnB como um todo. Porém, há que se ressaltar que o montante aqui apresentado em custos invisíveis, segundo a proposta de juros, multas e atualizações monetárias, não abrange todas as áreas de potencial ocorrência. Refere-se, portanto, a uma amostra probabilística, que deve ser aprofundada e ampliada às demais áreas e setores da universidade.

Além dos dados numéricos, o estudo também possibilitou a compreensão dos aspectos ligados à gestão da instituição. Verificou-se que falhas nos procedimentos de controle ligados aos trâmites internos e nos processos de pagamentos constituem as causas para o surgimento dos custos em questão. Diante disso, ressalta-se que o principal motivo argumentado pela DCF para a ocorrência de tais gastos está ligado à insuficiência orçamentária. Entretanto, essa falta de recursos é identificada, por 
vezes, apenas no momento de execução dos pagamentos, o que demanda novo processo de alocação e provoca um atraso ainda maior.

Há que se observar, entretanto, que algumas despesas, como as de energia elétrica, telefone e outras mais, são rotineiras e previsíveis. Portanto, os recursos referentes ao seu custeio devem estar planejados e garantidos, a fim de se evitarem esses atrasos e, consequentemente, os gastos com JMA.

Dessa maneira, visualiza-se que o problema emana de uma relação interpessoal, em que os agentes são os responsáveis pelas falhas do sistema como um todo. Assim, a teoria da agência possibilitou compreender como os conflitos de interesses entre o agente e o principal podem desencadear o surgimento desses custos invisíveis. Além disso, também apresenta as políticas de incentivo, que não devem ser descartadas dentro de um processo resolutivo. Em outras palavras, a existência de um conflito de interesse entre o administrador e a organização, conforme descreve o modelo principal agente, impede a resolução do conflito, e um sistema de incentivos que alinhe os interesses desses dois atores é necessário (por exemplo, algum mecanismo que assegure ao administrador que ele não seja penalizado ao reportar esse tipo de falha no sistema ou ainda que o incentive a reduzir o tempo entre o recebimento da conta e seu pagamento).

Por fim, torna-se claro que gastos desnecessários devem ser mapeados e minimizados/cortados, na busca de um melhor ajuste das contas. E diante da dificuldade financeira que a universidade apresenta em garantir a execução das suas despesas, tais medidas são extremamente necessárias. Nesse sentido, os custos invisíveis podem representar uma parcela considerável para o processo de alocação de recursos, quando bem identificados e mensurados.

\section{Referências bibliográficas}

AKERLOF, G, The market for "lemons": quality uncertainty and the market mechanism. The Quarterly Journal of Economics, v. 84, n. 3, p. 488-500, Aug. 1970.

ALCHIAN, A.A. Economic forces at work. Liberty Fund Inc., 1977.

Albuquerque, C. Manoel; Medeiros, M. Bastos; Feisó, P. Henrique. Gestão de finanças públicas. Fundamentos e práticas de planejamento, orçamento e administração financeira com responsabilidade fiscal. 2a ed. Brasília: Editora Gestão Pública, 2008.

AleXAndRe, N. P. Gestão dos custos invisíveis. Monografia (Especialização) Curso de Especialização (MBA) para Executivos do Centro de Ciências da Administração da Esag. Florianópolis: Udesc, 2002.

Alonso, Marcos. Custos no setor Público. Revista do Serviço Público, ano 50, n. 1, jan-mar 1999. 
ANDRADE, A.; RossettI, J. P. Governança corporativa: fundamentos e tendências. São Paulo: Atlas, 2004.

BIANCHI, M. A. Controladoria como um mecanismo interno de governança corporativa $e$ de redução dos conflitos de interesse entre principal e agente. Dissertação de Mestrado, Universidade do Vale do Rio dos Sinos. São Leopoldo-RS, 2005.

BIANCHI, M. E.; NASCIMENTO, A. A controladoria como um mecanismo interno de governança corporativa e de redução dos conflitos de interesse entre principal e agente. In: CONGRESSO INTERNACIONAL DE CUSTOS, 9., 2005, Florianópolis, SC, Brasil.. Anais... Florianópolis, 2005. Disponível em: <http://anaiscbc.emnuvens.com.br/ anais/article/viewFile/2052/2052>. Acesso em: 21/11/21014.

BRASIL. Lei no 12.952, de 20 de janeiro de 2014 (Lei Orçamentária Anual - LOA). Estima a receita e fixa a despesa da União para o exercício financeiro de 2014. Site do Planalto, Brasília, 2014. Disponível em: <http://www.planalto.gov.br/ccivil_03/_ Ato2011-2014/2014/Lei/L12952.htm>. Acesso em: 20 de maio de 2015.

COASE, R.H. The nature of the firm. Economica, v.16, n.4, p. 386-405, 1937.

COASE, Ronald. The problem of social cost. Journal of Law and Economics, 1960.

CORRÊA, B.; LOPES, V. A aplicação do custo de oportunidade na seleção de alternativas de investimento em uma indústria de confecção de jeans da cidade de Fortaleza. In: Congresso Brasileiro de Custos, 16.,Fortaleza, 2009. Anais... Fortaleza, 2009.

Delgado, B. E.; CAMPOS, A. A saúde suplementar brasileira e as assimetrias de informação. In: ENCONTRO NACIONAL - CONSELHO NACIONAL DE PESQUISA E PÓS-GRAduAÇÃo EM DIREITO (CONPEDI), 21., Uberlândia, 2012. Anais... Uberlândia: Conpedi, 2012. Disponível em <http://www.publicadireito.com.br/ artigos/?cod=fa14d4fe2f19414d>. Acesso em 20/11/2014.

FEMENICK, T.R. A problemática e a solução para os "custos invisíveis" e "custos ocultos". Revista do UNI-RN, 4(1/2), p.49, 2005.

Ferreira, G.; Gonçalves, W.; Pedroxo, E. E.; TAkitane, I. A economia dos custos de transação sob uma análise crítica: perspectivas de aplicação no agronegócio. In: CONGRESSO DA SOBER - INSTITUIÇÕES, EFICIÊNCIA, GESTÃO E CONTRATOS NO SISTEMA Agroindustrial, 43., Ribeirão Preto, julho de 2005. Anais... Ribeirão Preto, 2005.

FERREIRA, I. D. Custos invisíveis: a equidade intergeracional e o custo ambiental da disposição de rejeitos nucleares de Angra 3. Dissertação de Mestrado. Universidade de Brasília, 2014.

Horngren, C.; Foster, G. E.; DATAR, S. Contabilidade de custos. Tradução José Luiz Paravato. 9. ed. Rio de Janeiro: Editora LTC, 2000.

JENSEN, M.; MECKLING, W. Theory of the firm: managerial behavior, agency cost, and ownership structure. Journal of Financial Economics, p. 305-360, 1976.

KUPFER, D. E.; HASENCLEVER, L. Economia industrial. Fundamentos teóricos e práticos no Brasil. 2. ed. Rio de Janeiro: Ed. Elsevier, 2013.

LAFFONT, JJ,; MARTIMORT, D. The theory of incentives: the principal-agent model. Princeton University Press, 2009. 
LIMA, M. A. A. A estrutura e as ferramentas da intervenção-pesquisa socioeconômica nas empresas e demais organizações. Revista de Administração de Empresas, São Paulo, p. 21-30, jan./mar.1991.

NASCIMENTO, A. M.; SouZA, M. A. S. Custos de oportunidade: evolução e mensuração. In: Congresso BRAsileiro de Custos, 10., Guarapari, 2003. Anais... Guarapari, 2003. PAdoveze, C. L. Curso básico gerencial de custos. 2. ed. São Paulo: Pioneira Thomson Learning, 2006.

ZAFFANI, C.A. Cuidado com os custos invisíveis. Revista Boletim CRC/SP, São Paulo, $\mathrm{n}$. 158, p. 19-22, mar/maio 2006.

ZYLBERSTAJN, D.; NEVES, M. (Orgs.). Economia e gestão dos negócios agroalimentares. Indústria de alimentos, indústria de insumos, produção agropecuária, distribuição. São Paulo: Pioneira Thompson Learning, 2000.

ZYLBERSTAJN, D. Costs, transactions and transactions costs: are there simple answers for complex questions? Working Paper, São Paulo, n. 3/006, fev. 2003. Universidade de São Paulo - Faculdade de Economia e Administração. Disponível em: <http// www.ead.fea.usp.br/wpapers >. Acesso em: 10/10/2014.

WANG, N., Measuring transaction costs: an incomplete survey. Ronald Coase Institute, Working Paper Series, n. 2, fev. 2003. Disponível em: <http// www. Coase. org/research.htm >.

WILLIAMSON, O. E. The economic institutions of capitalism. New York: The Free Press, 1985.

WILliamson, O. E. The mechanisms of governance. New York: Oxford University Press, 1996.

Andrea Felippe Cabello

Doutora em Economia pela Universidade de Brasília (UnB) e professora adjunta da Universidade de Brasília (UnB). Contato: andreafc@gmail.com

Joelder Alves da silva

Mestre em Economia pela Universidade de Brasília (UnB) e servidor da Universidade de Brasília no cargo de Administrador.

Contato: joelder@unb.br 


\section{Anexos}

Faturas de energia elétrica - 2010 (Não foram encontradas faturas referentes ao consumo dos meses de novembro e dezembro de 2010).

\begin{tabular}{|c|c|c|c|c|c|c|c|}
\hline $\begin{array}{l}\text { Mês de } \\
\text { consu- } \\
\text { mo }\end{array}$ & $\begin{array}{l}\text { Venci- } \\
\text { mento }\end{array}$ & $\begin{array}{l}\text { Valor total das } \\
\text { faturas (R\$) }\end{array}$ & $\begin{array}{l}\text { № fa- } \\
\text { turas } \\
\text { com } \\
\text { juros/ } \\
\text { multas }\end{array}$ & $\begin{array}{l}\text { Total de } \\
\text { Multas / } \\
\text { Juros (R\$) }\end{array}$ & $\begin{array}{l}\text { № de } \\
\text { faturas } \\
\text { sem } \\
\text { juros/ } \\
\text { multas }\end{array}$ & $\begin{array}{l}\text { Total } \\
\text { de } \\
\text { fatu- } \\
\text { ras }\end{array}$ & $\begin{array}{l}\% \text { de } \\
\text { faturas } \\
\text { com } \\
\text { juros/ } \\
\text { multas }\end{array}$ \\
\hline TODOS & & $2.812 .317,30$ & 51 & $41.687,98$ & 69 & 120 & $42,50 \%$ \\
\hline
\end{tabular}

Faturas referentes ao mês de Dezembro 2012

\begin{tabular}{|c|c|c|c|c|c|c|c|}
\hline $\begin{array}{l}\text { Mês } \\
\text { de } \\
\text { consu- } \\
\text { mo }\end{array}$ & Vencimento & $\begin{array}{l}\text { Valor total } \\
\text { das faturas } \\
\text { (R\$) }\end{array}$ & $\begin{array}{l}\text { № fa- } \\
\text { turas } \\
\text { com } \\
\text { juros/ } \\
\text { multas }\end{array}$ & $\begin{array}{l}\text { Total de } \\
\text { multas } \\
\text { /juros } \\
\text { (R\$) }\end{array}$ & $\begin{array}{l}\text { № de } \\
\text { faturas } \\
\text { sem } \\
\text { juros/ } \\
\text { multas }\end{array}$ & $\begin{array}{l}\text { Total de } \\
\text { faturas }\end{array}$ & $\begin{array}{l}\text { \% de fa- } \\
\text { turas com } \\
\text { juros/ } \\
\text { multas }\end{array}$ \\
\hline DEZ & $20 / 01 / 2013$ & $137.895,71$ & 1952 & $3.624,25$ & 549 & 2501 & $78,05 \%$ \\
\hline
\end{tabular}


RSP 